\title{
Characteristics of Hydraulic Lime using Low-grade Dolomitic Limestone
}

\author{
Ki-Yeon Moon, Moon-Kwan Choi, Jin-Sang Cho ${ }^{\dagger}$, Kye-Hong Cho, and Ji-Whan Ahn* \\ Department of Research and Development, Korea Institute of Limestone and Advanced Materials, Danyang 27003, Korea \\ *Mineral Resources Research Division, Korea Institute of Geoscience and Mineral Resources, Daejeon 34132, Korea
}

(Received December 17, 2015; Revised February 18, 2016; Accepted February 25, 2016)

\begin{abstract}
This study aims to produce dolomitic hydraulic lime (D-NHL) using domestic low grade dolomitic limestone and to determine the effect of adding blast furnace slag (BFS) and gypsum as part of an investigation of the hydration properties of D-NHL to increase the mechanical properties. The main mineral phases of D-NHL as a hydraulic lime binder were $\mathrm{Ca}(\mathrm{OH})_{2}, \mathrm{Mg}(\mathrm{OH})_{2}, \mathrm{C}_{2} \mathrm{~S}$, $\mathrm{C}_{3} \mathrm{~S}$, and $\mathrm{MgO}$ residues. $\mathrm{Ca}(\mathrm{OH})_{2}$ transformed into $\mathrm{CaCO}_{3}$ in D-NHL paste over the period of 28 days, but the carbonation of $\mathrm{Mg}(\mathrm{OH})_{2}$ and the hydration of $\mathrm{C}_{2} \mathrm{~S}$ did not occur until hydration, after 28 days. Through an investigation of the hydration properties of D-NHL pastes mixed with BFS and gypsum, Al-based compounds such as calcium aluminate hydrates $\left(\mathrm{C}_{4} \mathrm{AH}_{13}\right)$ and ettringite were observed at early hydration time. The compressive strength was improved due to the increased quantities of these hydration products. These results show that good performance results from the application of dolomitic hydraulic lime and that a high value product can be made from domestic waste materials.
\end{abstract}

Key words : Dolomite, Natural hydraulic lime, Low-grade limestone, Hydration, Blast furnace slag

\section{Introduction}

$\mathrm{H}_{\mathrm{u}}^{\mathrm{s}}$ draulic lime, according to EU standard, is made by using a low-grade limestone which has high $\mathrm{SiO}_{2}$ contents. It is categorized into NHL (natural hydraulic lime), HL (hydraulic lime), and FL (formulated lime), and again divided into three grades according to compressive strength on 28 days of material age. ${ }^{1,2)}$ Because it has a long-term curing mechanism in which carbonation and hydration are complicatedly occurred, porous structure is formed inside hardened body, therefore by itself showing environmentally excellent properties such as constant temperature, constant humidity, anti-fungal, and absorption of hazardous substances. $^{1,3,4)}$ Further, hydraulic lime has an excellent size stability and reworking properties as compared with nonhydraulic lime, and efflorescence is prominently low. Hydraulic lime can be implemented in various usages such as finishing material, joining material, and filling material irrespective of structure is old and new structures. However, limestone which is suiting to manufacture conventional hydraulic lime is Ca-base limestone, thus scope of low grade limestone capable to be implemented in the hydraulic lime is limited. ${ }^{1,5}$

In case of dolomite, it is listed as a non-hydraulic limestone binder in EU standard with the name DL (dolomitic lime), and is specified to be used in the similar usage as Cabase hydraulic lime binder. ${ }^{1)}$ However, a Mg-base lime

${ }^{\dagger}$ Corresponding author : Jin-Sang Cho

E-mail : chsang@kilam.re.kr

Tel : +82-43-422-2094 Fax : +82-43-422-5581 binder manufactured by using a dolomite has high $\mathrm{MgO}$ contents, thereby crack can be occurred by expansion during curing, and by shrinkage during dry curing, thus practical implementation and research literatures are very rare about Mg-base lime binder. ${ }^{6}$ Recently, some of the researchers proposed a common opinion that curing mechanism of dolomitic lime is not limited to air curing, and expected that it can be manufactured to a hydraulic lime, soundness can be secured against shrinkage and expansion by hydrates during long-term curing. ${ }^{6-8)}$

Therefore, in this study, it was aimed to investigate hydraulic lime (dolomitic hydraulic lime; D-NHL) using a domestically available low grade dolomitic limestone by referring to research outcomes of other researchers. Further, studies were performed about physical changes for the dolomitic hydraulic lime, in which inorganic admixtures were mixed to improve its physical properties, considered applicability of D-NHL prepared in this study, to review manufacture and implementation of D-NHL as a hydraulic lime binder.

\section{Experimental Procedure}

\subsection{Manufacturing Method of D-NHL}

Hydraulic lime is manufactured by using a low-grade limestone having high $\mathrm{SiO}_{2}$ and $\mathrm{Al}_{2} \mathrm{O}_{3}$. Since properties of hydraulic lime can be expressed according to contents of mineral phase which is produced during calcination, the mixing process of other materials for improving physical properties is not included in the hydraulic lime manufacturing process. ${ }^{1)}$ Therefore, manufacturing process of hydraulic lime includes somewhat simple processes like calcination, 


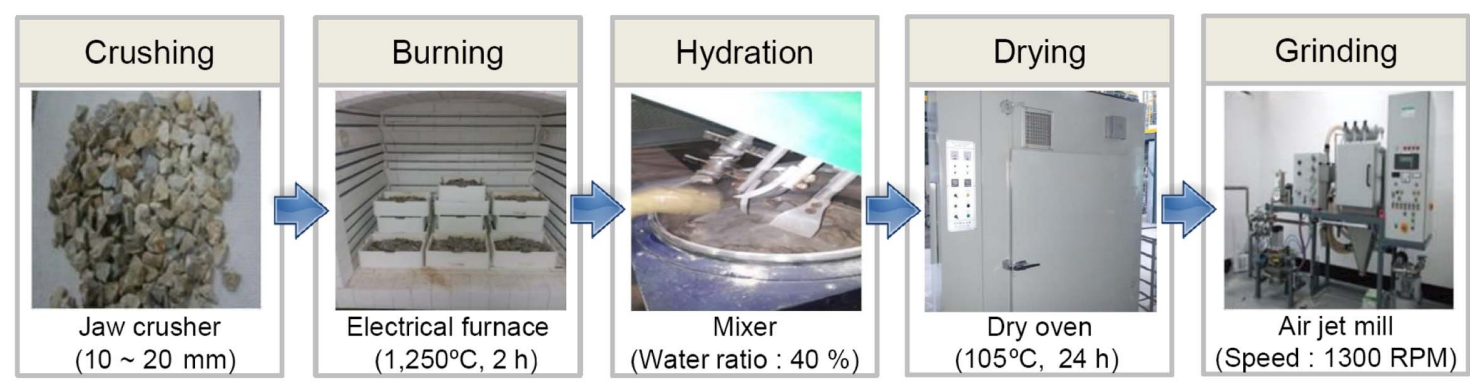

Fig. 1. Manufacturing process of D-NHL using low-grade dolomitic limestone.

hydration, and fine grinding. Also, if physical properties are needed to be improved, an adequate admixture is mixed in the finished sample. Fig. 1 shows manufacturing process of D-NHL using a low-grade dolomitic limestone. D-NHL was manufactured by the same process as general hydraulic lime.

Low-grade dolomitic limestone was collected from the mines of $\mathrm{H}$ company located at Danyang, Chungcheongbukdo, Korea. The collected limestone was crushed to a size (10 $\sim 20$ ) $\mathrm{mm}$ suiting to calcination and hydration process. Calcination was executed at $1,250^{\circ} \mathrm{C}$ for two hours, hydraulic lime was quickly cooled, and dry type hydration was continued at water ratio $0.4 \%$ (by weight) for $24 \mathrm{~h}$. The samples, after completing hydration, was dried at $(105 \pm 5)^{\circ} \mathrm{C}$ for $24 \mathrm{~h}$, and fine grinding was executed using an air jet mill to prepare DNHL with particle size of hydraulic lime less than $0.09 \mathrm{~mm}$, complying BS EN 459-1 : 2010. Paste and mortar were prepared to evaluate the physical properties of prepared DNHL itself according to curing, and changes in the physical properties were reviewed by mixing blast furnace slag (hereinafter referred to as BFS) to further raise applicability in the field.

\subsection{Paste Preparation and Analysis Method}

Paste of D-NHL single component and another paste made of ternary system D-NHL + BFS + gypsum were prepared to study hydration properties of D-NHL. In case of general hydraulic lime, hydration and carbonation are complicatedly occurred, thereby shows a long-term curing mechanism wherein physical properties are continuously improved even until one year. D-NHL prepared in this study also, though it was expected that complicate reaction of hydration and carbonation would occur as a lime binder to which hydraulic properties is added, since D-NHL has somewhat less contents of hydraulic mineral phase, it was intended to supplement physical properties in an experimental way by mixing mineral additives BFS and gypsum at a specific ratio.

Table 1 and Fig. 2 show chemical analysis results and mineral phase analysis results for BFS and gypsum. Chemical analysis of BSF revealed that it was composed of $\mathrm{CaO}$ at $42.44 \%, \mathrm{SiO}_{2}$ at $27.40 \%$, and $\mathrm{Al}_{2} \mathrm{O}_{3}$ at $14.79 \%$, indicating that $\mathrm{SiO}_{2}$ and $\mathrm{Al}_{2} \mathrm{O}_{3}$ were contained in large quantities. Mineral phase analysis showed that BFS contained as amor-
Table 1. Chemical Analysis of Blast Furnace Slag and Gypsum (\%)

\begin{tabular}{ccc}
\hline & BFS & Gypsum \\
\hline $\mathrm{Na}_{2} \mathrm{O}$ & 0.26 & 0.03 \\
$\mathrm{MgO}$ & 8.59 & 0.31 \\
$\mathrm{Al}_{2} \mathrm{O}_{3}$ & 14.79 & 0.61 \\
$\mathrm{SiO}_{2}$ & 27.41 & 1.37 \\
$\mathrm{P}_{2} \mathrm{O}_{5}$ & 0.10 & 0.01 \\
$\mathrm{SO}_{3}$ & 3.90 & 51.00 \\
$\mathrm{~K}_{2} \mathrm{O}$ & 0.82 & 0.09 \\
$\mathrm{CaO}$ & 42.45 & 42.20 \\
$\mathrm{TiO}_{2}$ & 0.60 & N.D. \\
$\mathrm{MnO}$ & 0.18 & N.D. \\
$\mathrm{Fe}_{2} \mathrm{O}_{3}$ & 0.57 & 0.18 \\
\hline
\end{tabular}

N.D. : Not detected

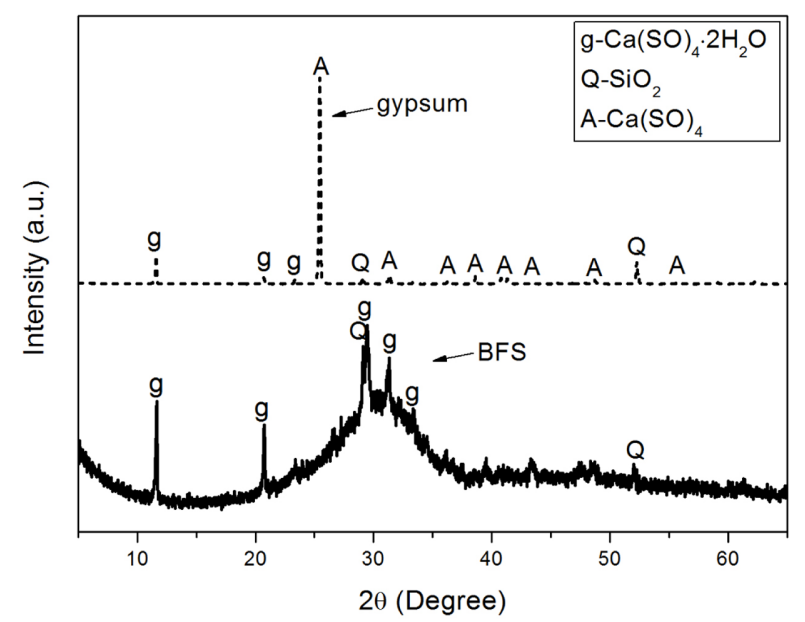

Fig. 2. XRD patterns of BFS and gypsum.

phous mineral, quartz $\left(\mathrm{SiO}_{2}\right)$ and dihydrate $\left(\mathrm{CaSO}_{4} \cdot 2 \mathrm{H}_{2} \mathrm{O}\right)$. Chemical analysis of gypsum showed that $\mathrm{CaO}$ at $42.20 \%$ and $\mathrm{SO}_{3}$ at $51.00 \%$ were main components, and minute quantities of $\mathrm{SiO}_{2}$ and $\mathrm{Al}_{2} \mathrm{O}_{3}$ were also contained, while mineral, phase analysis showed that gypsum was presented as anhydrous form. Gypsum has been used as an alkali stimulant which promotes potential hydraulic properties of BSF, and if ion elution of BSF is smooth, it would affect greatly on the overall types of hydrates and production rate. Parti- 


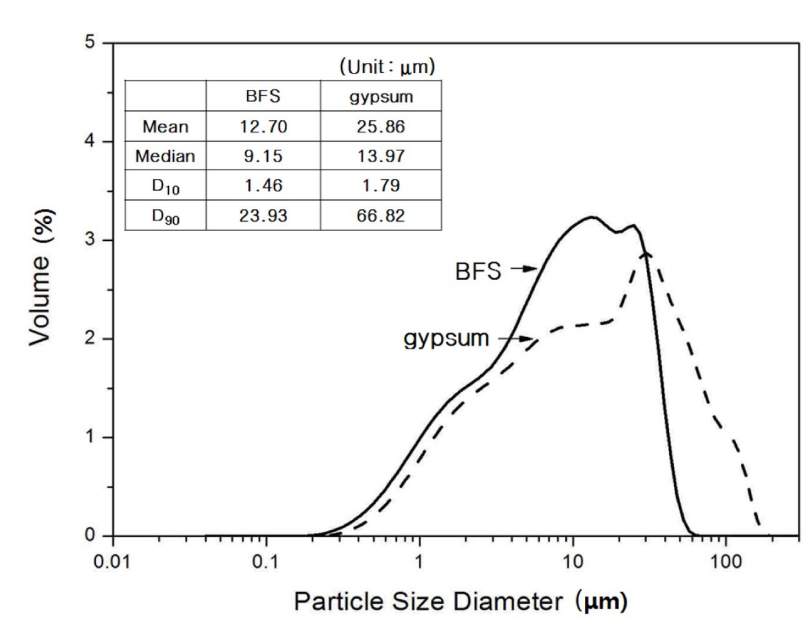

Fig. 3. Particle size distributions of BFS and gypsum.

cle size analysis as can be seen in Fig. 3 showed that overall particle size of BFS and gypsum was more than $10 \mu \mathrm{m}$, which is similar as large size particles normally presented in the hydraulic lime. Prepared paste was divided in the petri-dish as thin layer, hydration was stopped with acetone according to curing, and then dried before sampling, ready for analysis with instrument. Reaction properties of each sample which received pre-treatment according to each curing was investigated with X-ray diffraction analysis (XRD: D/max 2500V/P, Rigaku Co. Ltd. Japan), differential scan- ning calorimetry, thermogravimetric analyzer (TG/DSC: STA 449C Jupiter, NETZSCH Co, Ltd. Germany), scanning electron microscope (SEM: S-4300, HITACHI Co. Ltd. Japan), and porosity measurement (Auto Pore IV 9520, Micromeritics Co. Ltd. USA).

\subsection{Preparation of Mortar and Physical Properties Evaluation}

2.3.1 Compressive Strength Test

Mortar for measurement of compressive strength was prepared as per the specification in BS EN 459-2 : 2010. Mixing amount of water was adjusted to make the flow of fresh mortar at $(165 \pm 3) \mathrm{mm}$ to check difference of compressive strength under constant workability, and each sample was treated first with pre-mixing and then mortar was prepared as NHL (+ admixture) : sand : water $=1: 3: \mathrm{x}$ (flow $(165 \pm 3)$ $\mathrm{mm})$. Size of specimen was set at $(40 \times 40 \times 160) \mathrm{mm}$, and mortar was tamped using a vibrating table after dividing it into two layers. Mortar was cured under the curing temperature at $20^{\circ} \mathrm{C}$ relative humidity at $95 \%$ and compressive strength was measured at 7 days and 28 days. For the part on which load was imposed, load was set at $(40 \times 40 \times 40)$ $\mathrm{mm}$ cut area towards length, while the load speed was set at $144 \mathrm{kN} / \mathrm{min}$. Material mixing ratio and sample names of DNHL mortar are presented in Table 2.

\subsubsection{Air Contents}

According to EU Standard, hydraulic lime has a difference

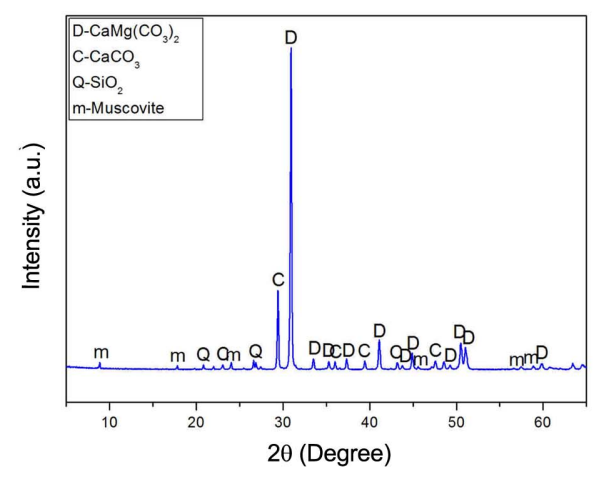

(a) low grade dolomitic limestone

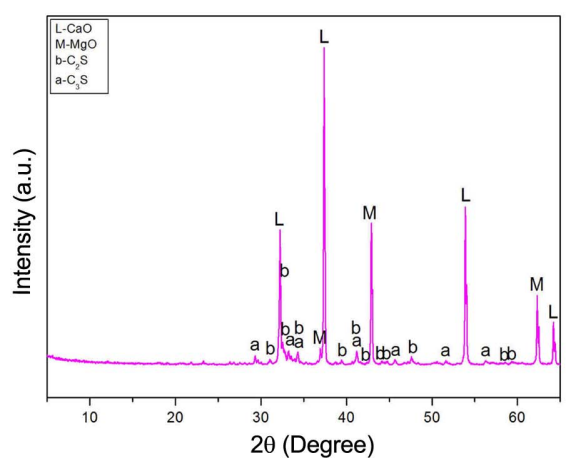

(b) sample calcined at $1250^{\circ} \mathrm{C}$ for $2 \mathrm{~h}$

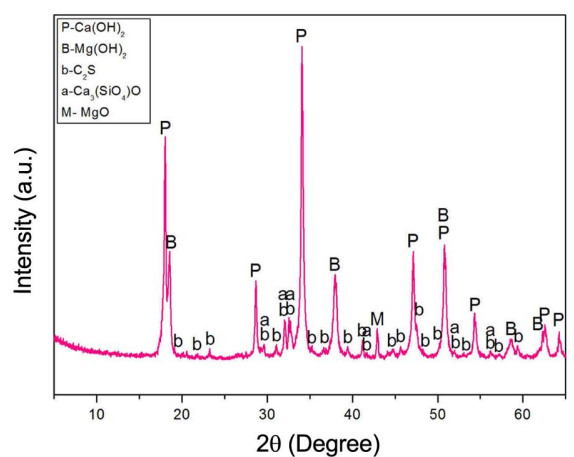

(c) D-NHL

Fig. 4. XRD patterns of raw material, calcination sample and D-NHL. 
Table 2. Mixing Ratio and Sample Designation of D-NHL Samples

\begin{tabular}{|c|c|c|c|c|c|}
\hline \multirow{2}{*}{ Raw materials } & \multirow{2}{*}{ BFS mixing ratio } & \multirow{2}{*}{ Gypsum } & \multicolumn{2}{|c|}{ Water ratio } & \multirow{2}{*}{ Sample designation } \\
\hline & & & Paste & Mortar & \\
\hline \multirow{4}{*}{$\begin{array}{l}\text { Domestic } \\
\text { D-NHL }\end{array}$} & $0 \%$ & $0 \%$ & \multirow{4}{*}{$\begin{array}{c}60 \% \\
\text { (by weight) }\end{array}$} & \multirow{4}{*}{$\begin{array}{c}\text { Flow } \\
(165 \pm 3) \mathrm{mm}\end{array}$} & D-NHL \\
\hline & $10 \%$ & \multirow{3}{*}{$3 \%$} & & & D-S10-g \\
\hline & $20 \%$ & & & & D-S20-g \\
\hline & $30 \%$ & & & & D-S30-g \\
\hline
\end{tabular}

in the air contents according to water contents in the mortar. In case of D-NHL, mortar was prepared with a flow ratio at $(165 \pm 3) \mathrm{mm}$ corresponding to medium-grade because correct grade was difficult to classify for D-NHL. Further, air content from the mortar made of NHL : sand : water $=1: 3:$ Flow $(165 \pm 3) \mathrm{mm}$ as per EU standard was measured, while it was not cured by using a testing device having capacity $1 \mathrm{~m}^{3}$ with a compressive method.

\subsubsection{Soundness}

$(25 \pm 0.1) \mathrm{g}$ of D-NHL was made as paste having water ratio at $60 \%$, and sample was prepared with diameter 50 $\mathrm{mm}$ and height $10 \mathrm{~mm}$. According to EU standard, stickiness of paste should enable to handle sample by hands. However, that stickiness would not be constant, thus paste was made with an adequate water ratio. Prepared paste was cured at $20^{\circ} \mathrm{C}$ and relative humidity at $95 \%$ for $48 \mathrm{~h}$ before proceeding experiment. Diameter of all the samples were measured twice before experiment, and average diameter $\left(D_{e}\right)$ was calculated.

Sample was left under steam at $(85 \sim 95)^{\circ} \mathrm{C}$ for $180 \mathrm{~min}$., and sample diameter $\left(D_{e}\right)$ was measured after steaming. Soundness of samples was measured by applying changes in diameter in the Equation 1 before and after steaming.

$$
\text { Soundness }=\left(D_{e}-D_{i}\right)
$$

Where, $D_{i}$ is the average sample diameter before steaming, $D_{e}$ is the average sample diameter after steaming

\subsubsection{Setting}

Water ratio was set to make gap at $(6 \pm 2) \mathrm{mm}$ between base plate and needle of Vicat apparatus, and paste was place in the mold having diameter $(75 \pm 10) \mathrm{mm}$ and height $(40 \pm 0.2) \mathrm{mm}$ for curing at $20^{\circ} \mathrm{C}$ and relative humidity at $95 \%$ for $30 \mathrm{~min}$., and then initial setting time was measured. After completing measurement of initial setting time, mold was turned down to measure final setting time for bottom of specimen.

\section{Results and Discussion}

\subsection{Manufacture of D-NHL}

Generally, raw materials which are utilized to manufacture hydraulic lime are low-grade limestones having high $\mathrm{SiO}_{2}$ and $\mathrm{Al}_{2} \mathrm{O}_{3}$ contents. During calcination process, $\mathrm{CaO}$ is produced by thermal degradation of $\mathrm{CaCO}_{3}$, and $\mathrm{CaO}$ reacted with $\mathrm{SiO}_{2}$ or $\mathrm{Al}_{2} \mathrm{O}_{3}$ through solid state reaction to produce hydraulic minerals such as $\mathrm{C}_{2} \mathrm{~S}, \mathrm{C}_{3} \mathrm{~S}$, and $\mathrm{C}_{3} \mathrm{~A}$. According to contents of mineral phase thus produced, hydration properties of hydraulic binder differ. Those researchers, who proposed that dolomitic lime can show hydraulic properties, forecasted that semi hydraulic lime would match hydraulic lime having somewhat lower hydraulic lime. ${ }^{6}$ Table 3 shows chemical analysis result of low-grade dolomitic limestone used as a raw material for D-NHL production, showing $\mathrm{SiO}_{2}$ at $5.18 \%$ and $\mathrm{MgO}$ at $14.44 \%$, which indicates that the dolomitic limestone is very low-grade as compared with general industrial purpose limestone and contains large amount of $\mathrm{SiO}_{2}$ and $\mathrm{MgO}$. Fig. 4 shows XRD analysis results of raw materials used for manufacture of D-NHL in this study. Fig. 4(a) shows lowgrade dolomitic limestone, (b) shows sample after calcination at an optimum calcination temperature in which solid phase reaction can take place, and (c) shows analysis results of D-NHL ground to comply EU standard after dry type hydration of calcined sample. Major mineral phases of the lowgrade dolomitic limestone in Fig. 4(a) are $\mathrm{CaCO}_{3}, \mathrm{CaMg}\left(\mathrm{CO}_{3}\right)_{2}$, $\mathrm{SiO}_{2}$, and muscovite, having higher $\mathrm{SiO}_{2}$ contents than general high grade limestone. Besides, they contain high amount of $\mathrm{CaCO}_{3}$ and $\mathrm{CaMg}\left(\mathrm{CO}_{3}\right)_{2}$, thus expected to produce hydraulic mineral phase smoothly by solid phase reaction after thermal decomposition. After calcination, major mineral phase of low-grade dolomitic lime (Fig. 4(b)) were $\mathrm{CaO}, \mathrm{MgO}, \mathrm{C}_{2} \mathrm{~S}$, and $\mathrm{C}_{3} \mathrm{~S}$, revealing that $\mathrm{MgO}$ was produced by thermal degradation of $\mathrm{CaMg}\left(\mathrm{CO}_{3}\right)_{2}$, while $\mathrm{C}_{2} \mathrm{~S}$ and $\mathrm{C}_{3} \mathrm{~S}$ were produced by solid phase reaction. In case of finally produced D-NHL (Fig. 4(c)), $\mathrm{Ca}(\mathrm{OH})_{2}$ and $\mathrm{Mg}(\mathrm{OH})_{2}$, which attribute carbonation and hydrate production, were presented in a large quantity. Hydraulic mineral phases such as $\mathrm{C}_{2} \mathrm{~S}$ and $\mathrm{C}_{3} \mathrm{~S}$, were also remained, indicating that complicated curing would be proceeded. Particle analysis of D-NHL in Fig. 5 shows that average particle size is lower than $90 \mu \mathrm{m}$, complying EU standard. These compositional mineral phases of

Table 3. Chemical Analysis of Low Grade Dolomitic Limestone (\%)

\begin{tabular}{cc}
\hline & Low-grade dolomitic limestone \\
\hline $\mathrm{MgO}$ & 14.44 \\
$\mathrm{Al}_{2} \mathrm{O}_{3}$ & 1.04 \\
$\mathrm{SiO}_{2}$ & 5.18 \\
$\mathrm{CaO}$ & 33.99 \\
$\mathrm{Fe}_{2} \mathrm{O}_{3}$ & 0.75 \\
\hline
\end{tabular}


D-NHL are same as the manufacturing properties of general hydraulic lime, which implies that D-NHL manufacture is possible by utilizing domestically available raw limestone.

\subsection{Hydration and Physical properties of D-NHL}

Curing mechanism as a hydraulic lime was checked by investigating hydration properties of D-NHL and changes in mineral phase by hydration and carbonation were investigated. D-NHL paste was prepared and changes in mineral phase according to curing was reviewed. XRD analysis revealed that major mineral phases of D-NHL were $\mathrm{Ca}(\mathrm{OH})_{2}, \mathrm{CaCO}_{3}, \mathrm{Mg}(\mathrm{OH})_{2}, \mathrm{MgO}$, and $\mathrm{C}_{2} \mathrm{~S}$ as shown in Fig. 6 . Part of $\mathrm{Ca}(\mathrm{OH})_{2}$ was converted to $\mathrm{CaCO}_{3}$ by carbonation, and $\mathrm{CaCO}_{3}$ peak was increased as curing was increased. It indicates that carbonation was continuously progressed, and remaining $\mathrm{Ca}(\mathrm{OH})_{2}$ also would attribute carbonation when it enters into a long curing after 28 days. However, in case of $\mathrm{Mg}(\mathrm{OH})_{2}$, there was no changes in the peak according to curing. Further, carbonates and hydrates including $\mathrm{MgCO}_{3}$ which is a carbonate of $\mathrm{Mg}(\mathrm{OH})_{2}$ were not pre-

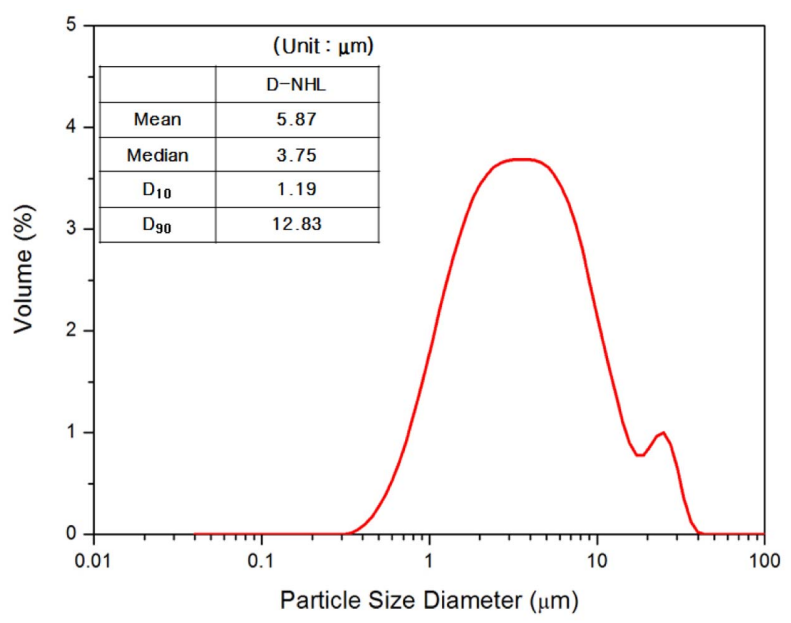

Fig. 5. Particle size distribution of D-NHL.

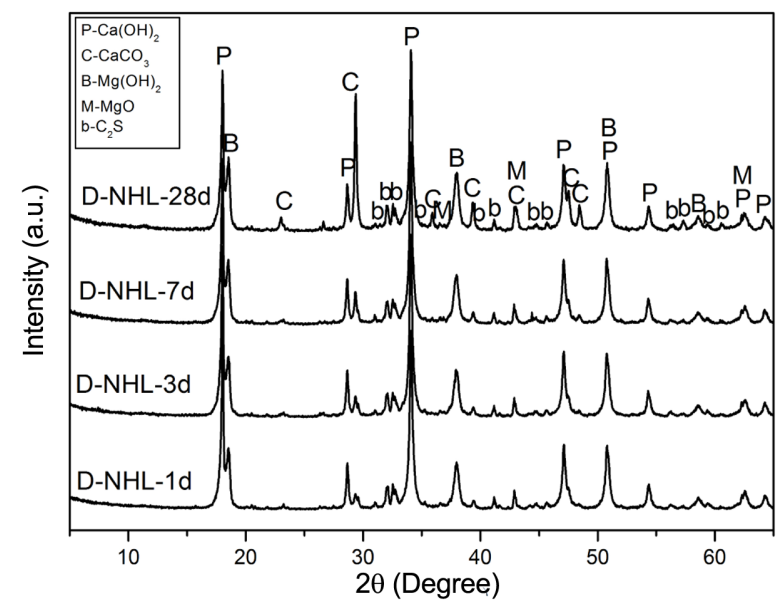

Fig. 6. XRD patterns of D-NHL paste with curing. sented. According to preceding literatures, carbonation of $\mathrm{Mg}(\mathrm{OH})_{2}$ is difficult to be proceeded under atmosphere, and physical properties should be observed for at least some years to check carbonates. ${ }^{7,8)} \mathrm{Mg}(\mathrm{OH})_{2}$ included in D-NHL, prepared in this study, also might exhibited the same trend in the preceding studies. It is judged that additional research has to be performed, which can prove physical properties change and soundness of $\mathrm{Mg}$ base hydrate in terms of a long-term reactivity, in order to propose a potential for the production of lime binder as a high value added product of low-grade dolomitic limestone. For more accurate approach about mineral phases that could be confirmed by the XRD analysis, DSC analysis was carried out (Fig. 7).

DSC analysis results showed that endothermic peaks by thermal decomposition of $\mathrm{Mg}(\mathrm{OH})_{2}, \mathrm{Ca}(\mathrm{OH})_{2}$, and $\mathrm{CaCO}_{3}$ were clearly formed at near $400^{\circ} \mathrm{C}, 500^{\circ} \mathrm{C}$ and $800^{\circ} \mathrm{C}$. Further, some of the endothermic peaks at near $100^{\circ} \mathrm{C}$, which was corresponding to thermal decomposition temperature of C-S-H phase produced by hydration of $\mathrm{C}_{2} \mathrm{~S}$, were appeared. However, peaks by hydrate and carbonate of $\mathrm{Mg}(\mathrm{OH})_{2}$ could not be found. This result shows a similar trend with the XRD analysis result.

For the physical properties of hydraulic lime complying EU standard, mandatory measurement items and properties values corresponding to each item are specified. Compressive strength is one of the basic properties for evaluations that can forecast practical implementation of hydraulic lime. Fig. 8 shows measurement results of compressive strength for the D-NHL mortar prepared as per EU standard, which shows increases in the compressive strength as curing was increased. This enhancement of strength might be because inner compactness was raised by the reaction product which was produced by carbonation and hydration. While, compressive strength of hydraulic lime as per EU standard is specified as at least more than $2 \mathrm{MPa}$ on the 28 days. However, in case of D-NHL prepared in this study, it showed a low compressive strength as $1 \mathrm{MPa}$ on 28 days, which does not comply EU standard. Same as the result from XRD analysis, content of $\mathrm{Ca}(\mathrm{OH})_{2}$

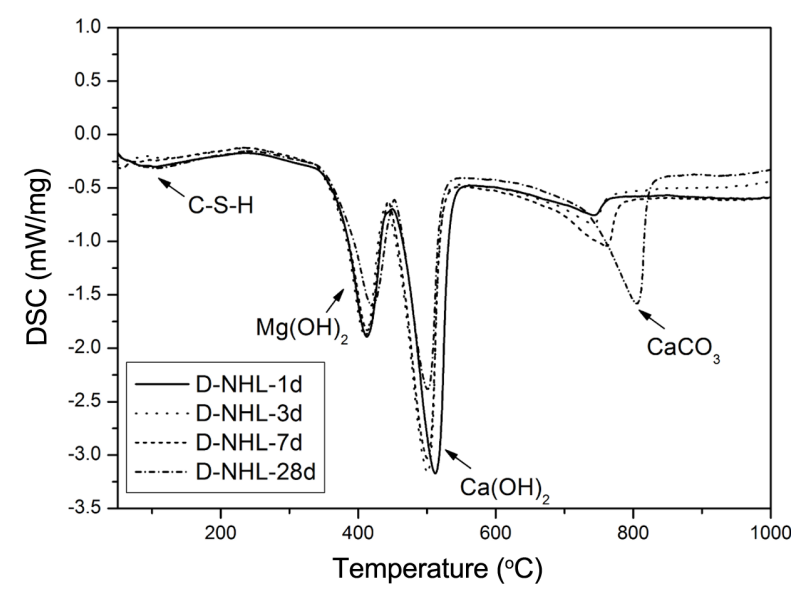

Fig. 7. DSC curves of D-NHL paste with curing. 


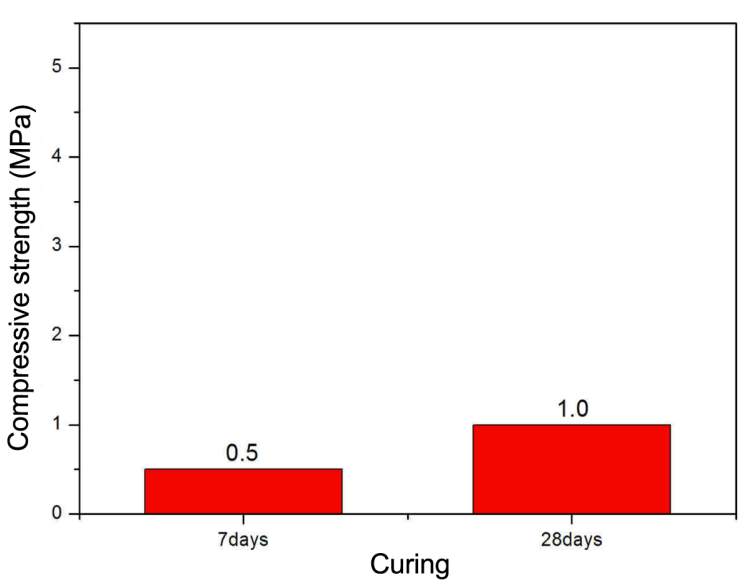

Fig. 8. Compressive strength of D-NHL mortar with curing.

Table 4. Physical Properties of D-NHL according to BS EN 459-1:2010

\begin{tabular}{cccc}
\hline \multirow{2}{*}{ Air content (\%) } & $\begin{array}{c}\text { Soundness } \\
(\mathrm{mm})\end{array}$ & \multicolumn{2}{c}{ Setting time $(\mathrm{h})$} \\
\cline { 3 - 4 } & -1.00 & Intial & Final \\
\hline 1.10 & 72 & 168 over \\
\hline
\end{tabular}

which could not be converted to $\mathrm{CaCO}_{3}$ by carbonation was high, and durability enhancement of hardened body might be very slowly appeared due to $\mathrm{C}_{2} \mathrm{~S}$ and $\mathrm{Mg}(\mathrm{OH})_{2}$, which have a low reactivity. Such expression of strength is due to mineral phase of D-NHL itself, thus research about how mineral phase of D-NHL behaviors in long-term physical properties might be required.

Table 4 shows measurement results of physical properties for D-NHL performed as per physical properties measurement items of hydraulic lime that is specified in BS EN 459$1: 2010$. The specification of physical properties of hydraulic lime according to EU standard is air contents within 5\%, soundness within $\pm 2 \mathrm{~mm}$, and in case of setting, initial setting for more than one hour, and final setting time within 40 h. Physical properties values of D-NHL as in Table 4 showed air contents $1.10 \%$, soundness $-1.00 \mathrm{~mm}$, and properties values were in conformity with EU standard. However, the initial setting time $72 \mathrm{~h}$ for D-NHL in this study was not in conformity with physical properties of hydraulic lime specified in EU standard, while final setting time was more than $168 \mathrm{~h}$, which could not be confirmed as an accurate properties' value. This might be because non-availasility of C-S-H, and ettringite, or $\mathrm{Al}$ series compound such as $\mathrm{C}_{4} \mathrm{AH}_{13}$ that attribute initial setting. ${ }^{9,10)}$ Expression of overall physical properties of D-NHL showed the similar trend with hydraulic lime, and physical properties also were in conformity with EU standard except compressive strength and setting.

\subsection{Mineral Admixture Mixing Properties}

Hydraulic lime according to EU standard is categorized into NHL, HL, and FL, and its criteria is as per the types and characteristics of additives. In case of D-NHL, it has been confirmed that supplement of properties such as com- pressive strength and setting is required through physical properties study. Mineral admixtures BFS and gypsum were added to supplement physical properties of hydraulic lime and the results were observed, considered practical application and physical properties changes. Used mineral admixtures were those which are widely used to enhance physical properties of cement and lime binder, and these can be distinguished as HL (NHL + inorganic additives) among hydraulic limes as per EU standard. Fig. 9 shows XRD analysis results according to curing of paste wherein BFS and gypsum were mixed into D-NHL. Physical properties change was investigated by adding BFS at $10 \%, 20 \%$, and $30 \%$, respectively. Major mineral phases of the paste were $\mathrm{Ca}(\mathrm{OH})_{2}, \mathrm{CaCO}_{3}, \mathrm{Mg}(\mathrm{OH})_{2}, \mathrm{MgO}, \mathrm{C}_{2} \mathrm{~S}$, ettringite, gehlenite, $\mathrm{C}_{4} \mathrm{AH}_{13}$, and non-reacted gypsum. Overall mineral phases were similar regardless of admixture contents. As curing became extended, $\mathrm{CaCO}_{3}$ contents were increased, which indicated that carbonation was continuously progressed. Further, with only XRD analysis, production of calcium base hydrates by $\mathrm{C}_{2} \mathrm{~S}$ could not be confirmed. Besides, carbonates by $\mathrm{Mg}(\mathrm{OH})_{2}$ were not produced, which shows a similar trend with characteristics of mineral phase of DNHL as shown in Fig. 6. Still, according to addition of BFS and gypsum, ettringite at its initial setting time (as on 3 days) was produced.

DSC analysis results (Fig. 10) showed that endothermic peak by $\mathrm{Al}$ compound such as $\mathrm{C}_{4} \mathrm{AH}_{13}$ and etteringite appeared at near $120^{\circ} \mathrm{C}$, peaks at near $400^{\circ} \mathrm{C}$ by $\mathrm{Mg}(\mathrm{OH})_{2}$, at near $500^{\circ} \mathrm{C}$ by $\mathrm{Ca}(\mathrm{OH})_{2}$, and at near $800^{\circ} \mathrm{C}$ by $\mathrm{CaCO}_{3}$, showing the similar trends as XRD analysis results. The largest difference between DSC thermal analysis result of D-NHL in this study as in Fig. 7 and D-NHL with added BFS and gypsum thermal analysis results in Fig. 10 was that the peak was formed at near $120^{\circ} \mathrm{C}$ by $\mathrm{Al}$ base hydrates, which was increased as curing become extended, thus confirming hydrates production by adding mineral admixture.

Such Al base hydrates directly affect initial strength and setting of hardened body, thus supplementation of physical characteristics on the D-NHL by adding BFS and gypsum would be possible. However, the production of hydrates by increasing BFS contents was not large enough, which might be due to limited $\mathrm{SO}_{3}{ }^{2-}$ ion contents supplied by gypsum as against BFS contents. ${ }^{11)}$

Figure 11 shows compressive strength measurement results for D-NHL mortar with added BFS and gypsum, indicating increased in the compressive strength as BFS content was increased and curing was extended. Physical properties more than HL 2 could be appeared with compressive strength $3.08 \mathrm{MPa}$ on 28 days even by adding $10 \%$ of BFS, if analyzed with added BFS contents without considering gypsum contents which were at a constant level. When BFS was added at $20 \%$, physical properties more than equivalent of HL 5, which exhibited the best physical properties among hydraulic lime, could be obtained with more than $2 \mathrm{MPa}$ on 7 days and more than $5 \mathrm{MPa}$ on 28 days, respectively. Increases in the compressive strength by add- 


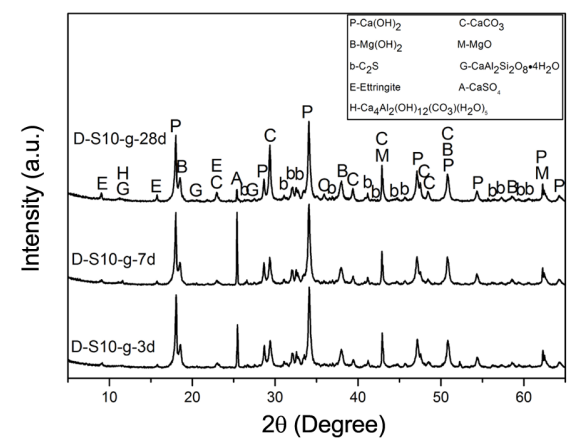

(a) D-NHL + BFS $10 \%+$ gypsum $3 \%$

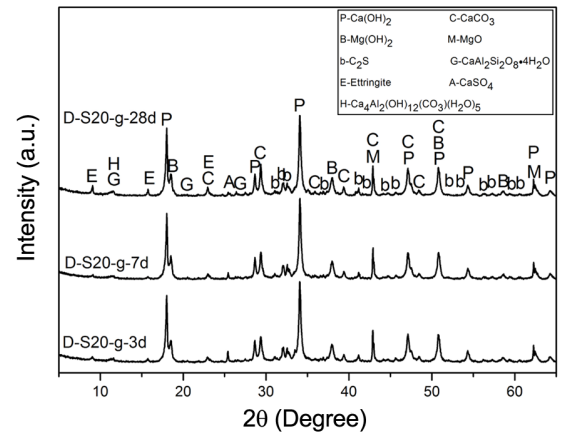

(b) D-NHL + BFS 20\% + gypsum $3 \%$

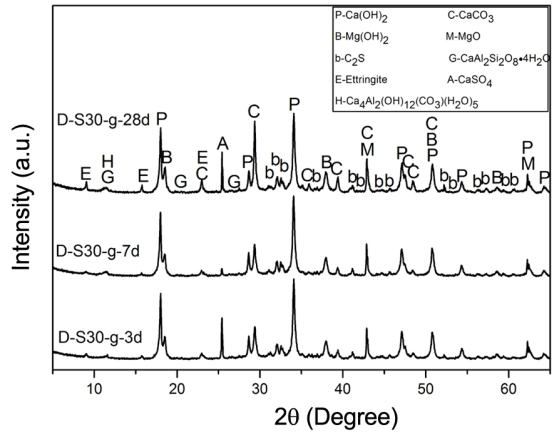

(c) D-NHL + BFS $30 \%+$ gypsum $3 \%$

Fig. 9. XRD patterns of D-NHL paste containing BFS and gypsum with curing.

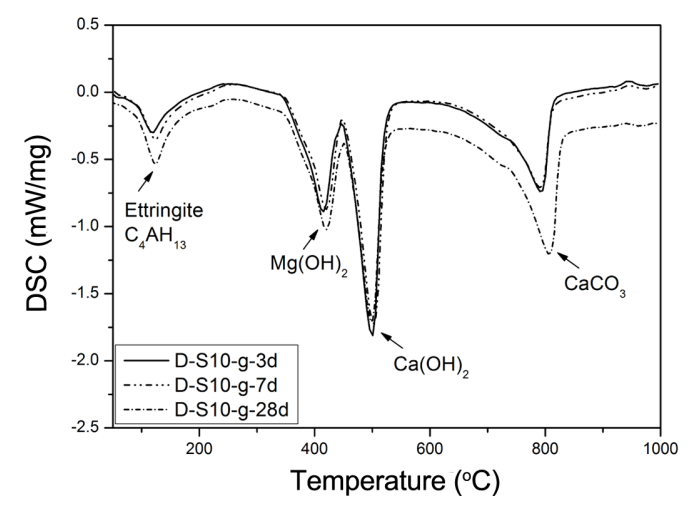

(a) D-NHL + BFS $10 \%+$ gypsum $3 \%$

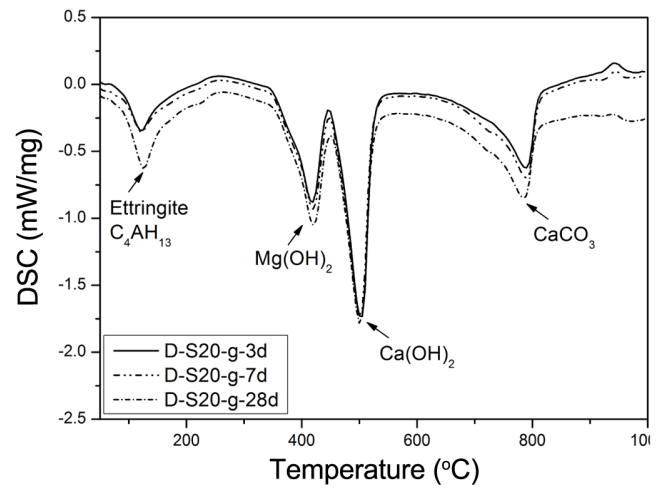

(b) D-NHL + BFS $20 \%+$ gypsum $3 \%$

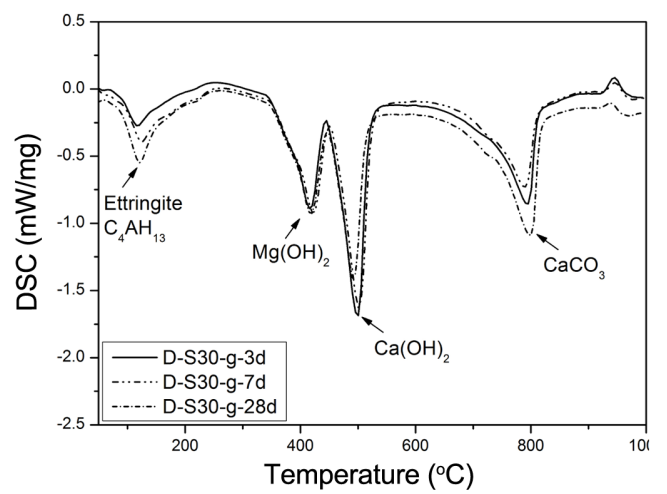

(c) D-NHL + BFS 30\% + gypsum 3\%

Fig. 10. DSC curves of D-NHL paste containing BFS and gypsum with curing. 


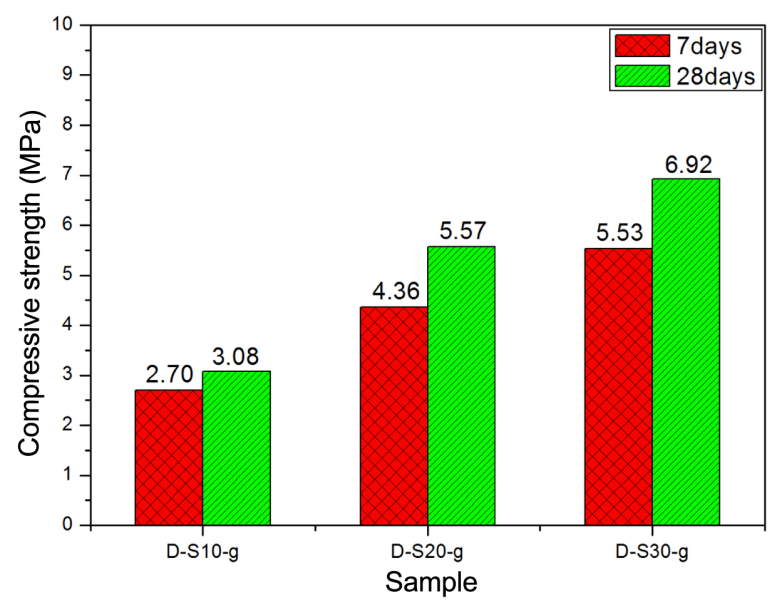

Fig. 11. Compressive strength of D-NHL mortars containing BFS and gypsum with curing.

ing BFS and gypsum, as shown in the XRD analysis results in Fig. 9 and DSC analysis as in Fig. 10, might be due to $\mathrm{Al}$ base compound which was produced from the initial stage of curing. While, expression of far excellent physical properties could be expected in the long-term when carbonation of $\mathrm{Ca}(\mathrm{OH})_{2}$ and hydration of hydraulic mineral phase was progressed after 28 days.

Table 5 shows physical properties evaluation results for ternary system D-NHL wherein BFS and gypsum were mixed. Air contents measurement results showed that as BFS contents were increased, air contents were also increased. Besides, higher values in overall than physical properties of D-NHL itself could be observed. Air contents were decreased as powder became increased. This might be due to increases in the air contents as admixture contents were increased since particle sizes of BFS and gypsum were larger than D-NHL particles (Fig. 3 and Fig. 5). As far as soundness is concerned, changes in the length was within $1.00 \mathrm{~mm}$ when additives were added, which was in conformity with EU standard. Meanwhile, initial setting time within $(13 \sim 18) \mathrm{h}$ and final setting time within $26 \mathrm{~h}$ were matching with the soundness levels HL $3.5 \sim$ HL 5. Difference in the setting time before and after adding admixture revealed that physical properties were improved by longer than $54 \mathrm{~h}$ for initial setting, while physical properties were improved by longer than $142 \mathrm{~h}$ for final setting time, which might be due to enhancement of hydrate production as mineral additives were added. Fig. 12 shows SEM analysis result for ternary system D-NHL paste wherein D-NHL

Table 5. Physical Properties of D-NHL Mixed with BFS and Gypsum according to BS EN 459-1:2010

\begin{tabular}{ccccc}
\hline & \multirow{2}{*}{$\begin{array}{c}\text { Air content } \\
(\%)\end{array}$} & $\begin{array}{c}\text { Soundness } \\
(\mathrm{mm})\end{array}$ & \multicolumn{2}{c}{ Setting time $(\mathrm{h})$} \\
\cline { 4 - 5 } & 2.00 & - & Initial & Final \\
\hline D-S10-g & 2.30 & -1.00 & 18 & 26 \\
D-S20-g & 3.30 & -1.00 & 13.5 & 20 \\
D-S30-g & 3.40 & & \\
\hline
\end{tabular}

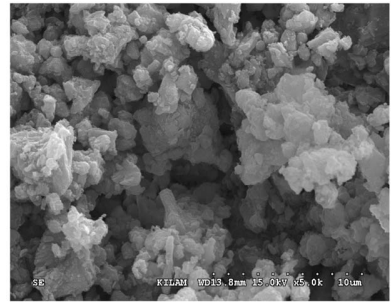

(a) D-NHL paste

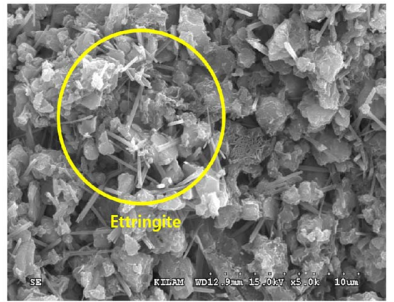

(b) D-NHL paste containing BFS $20 \%$ and gypsum $3 \%$
Fig. 12. SEM images of D-NHL and D-NHL pastes mixed with BFS and gypsum at 28 days.

paste, BFS, and gypsum were mixed. In the D-NHL itself, mineral phase by hydrates could not be found, but in the DNHL into which BFS and gypsum were added, minerals of ettringite and $\mathrm{C}_{4} \mathrm{AH}_{13}$ could be observed. Further, difference in the inner mineral phase by mineral additives could be confirmed same as in the XRD and DSC analysis results.

\section{Conclusions}

In this study, manufacturing possibility hydraulic lime as per EU standard was investigated by using a domestic low grade dolomitic limestone, and characteristics of paste and mortar were investigated through experiments for the commercialization of hydraulic lime.

(1) Dolomitic hydraulic lime (D-NHL) was prepared with EU standard using a domestic low-grade dolomitic lime. Major mineral phases of finally prepared D-NHL were $\mathrm{Ca}(\mathrm{OH})_{2}, \mathrm{Mg}(\mathrm{OH}), \mathrm{C}_{2} \mathrm{~S}$, and $\mathrm{C}_{3} \mathrm{~S}$, showing mineral phases that can be complicatedly appeared hydraulic lime curing mechanism carbonation and hydration.

(2) Final mineral phases of D-NHL paste on 28 days were $\mathrm{Ca}(\mathrm{OH})_{2}, \mathrm{Mg}(\mathrm{OH})_{2}, \mathrm{CaCO}_{3}, \mathrm{MgO}$, and $\mathrm{C}_{2} \mathrm{~S}$. As curing was extended, $\mathrm{CaCO}_{3}$ production was increased by carbonation of $\mathrm{Ca}(\mathrm{OH})_{2}$, but carbonation and hydration of $\mathrm{Mg}(\mathrm{OH})_{2}$ could not be confirmed. Evaluation of physical properties according to EU standard showed air contents $1.10 \%$ and soundness - $1.00 \mathrm{~mm}$, which complied EU standard. However, compressive strength and setting were somewhat low in the D-NHL, which did not follow EU standard.

(3) D-NHL mixed with BFS and gypsum was prepared in order to improve physical properties of D-NHL. Hydration characteristics study for the paste revealed that along with $\mathrm{CaCO}_{3}$ production by carbonation reaction, $\mathrm{Al}$ base compound such as ettringite and $\mathrm{C}_{4} \mathrm{AH}_{13}$ was produced at the initial stage of curing. As far as compressive strength is concerned, when $20 \%$ of BFS and gypsum were mixed, compressive strength higher than $2 \mathrm{MPa}$ on 7 days, higher than $5.0 \mathrm{MPa}$ on the 28 days, while initial setting time within maximum $18 \mathrm{~h}$ and final setting time within $26 \mathrm{~h}$ were achieved, showing that possible expression of physical properties higher than equivalent of medium grade among hydraulic limes as per EU standard.

(3) From the results of the present study, Mg-base lime 
binder displaying hydraulic properties same as D-NHL is easily manufactured by using a low grade dolomitic limestone, and practical application could be considered after supplementing some of the properties. Once manufacturing process of lime binder using low-grade limestone is commercialized, high value added industrial market could be newly formed as a plan for effective resources from waste domestically generated.

\section{Acknowledgments}

The present study was conducted with the support of research fund from Energy Technology Development Product (2013T100100021), the Korea Ministry of Trade, Industry and Energy.

\section{REFERENCES}

1. BS EN 459-1:2010 "Building lime. Part 1: Definitions, Specifications and conformity criteria," pp. 19-21 in BSI Standard Publication, 2010.

2. A. El-Turki, R. J. Ball, and G. C. Allen, "The Influence of Relative Humidity on Structural and Chemical Changes during Carbonation of Hydraulic Lime," Cement Concr. Res., 37 1233-40 (2007).

3. R. M. H. Lawrence, A Study of Carbonation in Nonhydraulic Lime Mortars, pp. 1-316, in PH.D. Thesis, University of
Bath, Bath, 2006.

4. R. Chan and V. Bindiganavile, "Toughness of Fibre Reinforced Hydraulic Lime Mortar. Part-1: Quasi-Static Response," Mater. Struct., 43 1435-44 (2010).

5. A. Kalagri, A. Miltiadou-Fezans, and E. Vintzileou, "Design and Evaluation of Hydraulic Lime Grouts for the Strengthening of Stone Masonry Historic Structures," Mater. Struct., 66 [43] 1135-46 (2010).

6. L. Chever, S. Pavı'a, and R. Howard, "Physical Properties of Magnesian Lime Mortar," Mater. Struct., 43 283-96 (2010)

7. J. Lanas and J. I. Alvarez, "Dolomitic Limes: Evolution of the Slaking Process under Different Conditions," Thermochim. Acta., 423 [1-2] 1-12 (2004).

8. R. M. Dheilly, A. Bouguerra, B. Beaudoin, J. Tudo, and M. Queneudec, "Hydromagnesite Development in Magnesian Lime Mortars," Mater. Sci. Eng. A, 268 [1-2] 127-31 (1999).

9. M. F. Rojas and M. I. Sa'nchez de Rojas, "Influence of Metastable Hydrated Phases on the Pore Size Distribution and Degree of Hydration of MK-Blended Cements Cured at 60 C," Cement Concr. Res., 35 [7] 1292-98 (2005).

10. W. Mechti, T. Mnif, B. Samet, and M. J. Rouis, "Effect of the Secondary Minerals on the Pozzolanic Activity of Calcined Clay: Case of Quartz," IJRRAS., 12 [1] 61-71 (2012).

11. I. Baur, P. Keller, D. Mavrocordatos, B. Wehrli, and C. A. Johnson, "Dissolution-Precipitation Behaviour of Ettringite, Monosulfate, and Calcium Silicate Hydrate," Cement Concr. Res., 34 [2] 341-48 (2004). 